\title{
Composite Polybenzimidazole Membrane with High Capacity Retention for Vanadium Redox Flow Batteries
}

\author{
Jacobus C. Duburg ${ }^{1}\left(\mathbb{D}\right.$, Kobra Azizi ${ }^{2}$, Søren Primdahl ${ }^{2}$, Hans Aage Hjuler 2,3 ${ }^{\mathbb{D}}$, Elena Zanzola ${ }^{1, * \mathbb{D}}$, \\ Thomas J. Schmidt ${ }^{1,4}$ (D) and Lorenz Gubler ${ }^{1}$ (D) \\ 1 Electrochemistry Laboratory, Paul Scherrer Institut, CH-5232 Villigen, Switzerland; \\ jacobus.duburg@psi.ch (J.C.D.); thomasjustus.schmidt@psi.ch (T.J.S.); lorenz.gubler@psi.ch (L.G.) \\ 2 Blue World Technologies, Egeskovvej 6C, DK-3490 Kvistgård, Denmark; kaz@blue.world (K.A.); \\ spr@blue.world (S.P.); hah@blue.world (H.A.H.) \\ 3 Danish Center for Energy Storage, Frederiksholms Kanal 30, DK-1220 Copenhagen K, Denmark \\ 4 Laboratory for Physical Chemistry, ETH Zurich, CH-8093 Zurich, Switzerland \\ * Correspondence: elena.zanzola@psi.ch; Tel.: +41-56-310-4738
}

check for updates

Citation: Duburg, J.C.; Azizi, K.; Primdahl, S.; Hjuler, H.A.; Zanzola, E.; Schmidt, T.J.; Gubler, L. Composite Polybenzimidazole Membrane with High Capacity Retention for Vanadium Redox Flow Batteries. Molecules 2021, 26, 1679. https:// doi.org/10.3390/molecules26061679

Academic Editors: Joanna Krakowiak, Petr Mazur and Peter Fischer

Received: 5 February 2021

Accepted: 9 March 2021

Published: 17 March 2021

Corrected: 30 June 2022

Publisher's Note: MDPI stays neutral with regard to jurisdictional claims in published maps and institutional affiliations.

Copyright: (c) 2021 by the authors. Licensee MDPI, Basel, Switzerland. This article is an open access article distributed under the terms and conditions of the Creative Commons Attribution (CC BY) license (https:// creativecommons.org/licenses/by/ $4.0 /)$.

\begin{abstract}
Currently, energy storage technologies are becoming essential in the transition of replacing fossil fuels with more renewable electricity production means. Among storage technologies, redox flow batteries (RFBs) can represent a valid option due to their unique characteristic of decoupling energy storage from power output. To push RFBs further into the market, it is essential to include low-cost materials such as new generation membranes with low ohmic resistance, high transport selectivity, and long durability. This work proposes a composite membrane for vanadium RFBs and a method of preparation. The membrane was prepared starting from two polymers, metapolybenzimidazole $(6 \mu \mathrm{m})$ and porous polypropylene $(30 \mu \mathrm{m})$, through a gluing approach by hotpressing. In a vanadium RFB, the composite membrane exhibited a high energy efficiency $(\sim 84 \%)$ and discharge capacity $(\sim 90 \%)$ with a $99 \%$ capacity retention over 90 cycles at $120 \mathrm{~mA} \cdot \mathrm{cm}^{-2}$, exceeding commercial Nafion ${ }^{\circledR}$ NR212 ( $82 \%$ efficiency, capacity drop from $90 \%$ to $40 \%$ ) and Fumasep ${ }^{\circledR}$ FAP-450 ( $\sim 76 \%$ efficiency, capacity drop from 80 to $65 \%$ ).
\end{abstract}

Keywords: polybenzimidazole; polypropylene; skin layer; support layer; interlocking interface; composite asymmetric membrane; vanadium redox flow battery; discharge capacity; capacity retention

\section{Introduction}

Among electrochemical energy storage technologies, redox flow batteries (RFBs) are very flexible. In particular, they have the unique advantage of decoupling energy storage from power output. Energy is stored in two external electrolyte-containing tanks, and charge/discharge reactions take place in an electrochemical reactor where the electroactive species, dissolved in the electrolyte solutions, undergo reversible redox reactions on the surface of porous carbon-based electrodes. Inside the electrochemical cell, a membrane is used as a separator between the two porous electrodes, functioning as a polymer electrolyte for selective transport of dissolved ionic species.

Specifically, membranes in a unit electrochemical cell, incorporated in an RFB setup, have the primary role of mediating the transport of ionic charges between the negative and the positive cell compartment, to allow each half-cell redox reaction to proceed in a continuous manner while electrons are exchanged via an external circuit [1]. At the same time, it is not desirable for the electroactive species to transfer across the membrane, as this may impair the coulombic efficiency, depolarize an electrode, pollute the product, reduce capacity retention, or cause other unwanted effects.

A large number of publications have focused on membranes for RFBs [2-4], where researchers proposed new designs and materials to increase stability and efficiency in this storage technology during prolonged charge/discharge cycling. Recent studies showed 
membranes consisting of an asymmetric architecture [5-7] and others comprising a porous support coated with a thin polymer layer to act as a barrier against the crossover of electroactive species (e.g., vanadium or organic molecules) [8-10]. Furthermore, the membrane design can become relevant on a technical scale in terms of investment costs. Indeed, if the membrane has a low ohmic resistance, the cell current density can be enhanced at a given round trip efficiency, leading to an increased power density. Accordingly, this can play a role in the size of the RFB stack, potentially leading to a reduction in the investment costs [6]. One method of reducing the ohmic resistance of the membrane is by reducing its thickness $[5,11,12]$. However, polymer electrolytes with a thickness in the micron range do not exhibit the mechanical strength to be used as free-standing films due to the risk of rupturing or developing pinholes during handling, cell assembly, and operation. To overcome this problem, the thin polymer electrolyte film can be strengthened with a porous support to provide mechanical robustness while allowing the access of a liquid electrolyte through its porous structure.

In terms of materials, membranes prepared from a polybenzimidazole (PBI) type polymer are receiving attention in the scientific community for their diverse applicability in various fields and uses, such as high-temperature proton exchange membrane fuel cells, electrodialysis, and organic solvent nanofiltration [13-17], including RFBs and, in particular, vanadium RFBs (VRFBs) [18-21]. Whereas commercial Nafion ${ }^{\circledR}$ is a cation exchange membrane (CEM), PBI in its pristine state is an insulator, but it develops the properties of an anion exchange membrane (AEM) in acidic conditions due to the uptake of electrolyte and the subsequent protonation of the nitrogen atoms in the imidazole group, thereby enhancing its barrier properties versus cations [22]. In addition, PBI's highly chemically stable backbone is particularly suitable for the oxidative and acidic environment of the VRFB [23], and studies have confirmed that a PBI pore size range from 0.5 to $2 \mathrm{~nm}$ can help to reduce vanadium ion crossover [23-25].

In this work, a composite asymmetric membrane for VRFBs and a method of preparation are described. The membrane was prepared starting from two polymeric layers, a thin meta-polybenzimidazole film ( $m$-PBI, $6 \mu \mathrm{m}$ thickness), herein called the "skin layer", and a hydrophobic mesoporous polypropylene layer TreoPore ${ }^{\circledR}$ PDA-30 (PP, $30 \mu$ m thickness, nonwoven, porosity $>60 \%$, Treofan, Raunheim, Germany), herein called the "support layer", through a gluing procedure by hot-pressing. This composite membrane was tested in a VRFB cell to assess performance and cycling stability over 90 consecutive charge/discharge cycles at $120 \mathrm{~mA} \cdot \mathrm{cm}^{-2}$. The cation exchange membrane Nafion ${ }^{\circledR} \mathrm{NR} 212$ and the anion exchange membrane Fumasep ${ }^{\circledR}$ FAP-450 were used as commercial benchmarks.

\section{Results}

The $m$-PBI was synthesized (see Section 4) and characterized using various techniques to study its purity and chemical stability. Proton nuclear magnetic resonance $\left({ }^{1} \mathrm{H}-\mathrm{NMR}\right)$ in dimethyl sulfoxide (DMSO) $-\mathrm{d}_{6}$, Fourier-transform infrared spectroscopy (FTIR), thermogravimetric analysis, and differential thermal analysis (TGA/DTA) were performed (see procedure in Section 4 and results in the Supplementary Materials). In addition, the inherent viscosity and molecular weight of the synthesized $m$-PBI were measured (see Supplementary Materials) according to previous work [26]. The inherent viscosity was $1.14 \mathrm{dL} \cdot \mathrm{g}^{-1}$, and the molecular weight, $58,000 \mathrm{Da}$, was determined using the empirical Mark-Houwink constants $\left(K=1.94 \times 10^{-4} \mathrm{dL} \cdot \mathrm{g}^{-1}\right.$ and $\left.\alpha=0.791\right)$ [27]. Later, it was demonstrated that a film of $m$-PBI remained stable over 4 months by performing an ex situ stability test in $1.6 \mathrm{M} \mathrm{V}(\mathrm{V})$ in $2 \mathrm{M} \mathrm{H}_{2} \mathrm{SO}_{4}$ and $0.05 \mathrm{M} \mathrm{H}_{3} \mathrm{PO}_{4}$ solution at room temperature. In this period of time, no $\mathrm{V}(\mathrm{IV})$ formed through the reaction of $m$-PBI with $\mathrm{V}(\mathrm{V})$, as confirmed by ultraviolet (UV)-visible light spectroscopy. In addition, for a film of $m$-PBI with a $39 \mu \mathrm{m}$ thickness, the water and electrolyte uptake, the in-plane conductivity, and an accelerated stress test in a solution of $0.2 \mathrm{M}$ cerium(IV) sulfate were determined and compared to those of standard commercial materials for VRFBs (Nafion ${ }^{\circledR}$ NR212 and Fumasep ${ }^{\circledR}$ FAP-450, respectively) (see results in the Supplementary Materials). 
Scanning electron microscopy (SEM) on a $6 \mu \mathrm{m} m$-PBI film was used as a qualitative study to investigate the morphology of the pristine polymer (Figure 1A)).
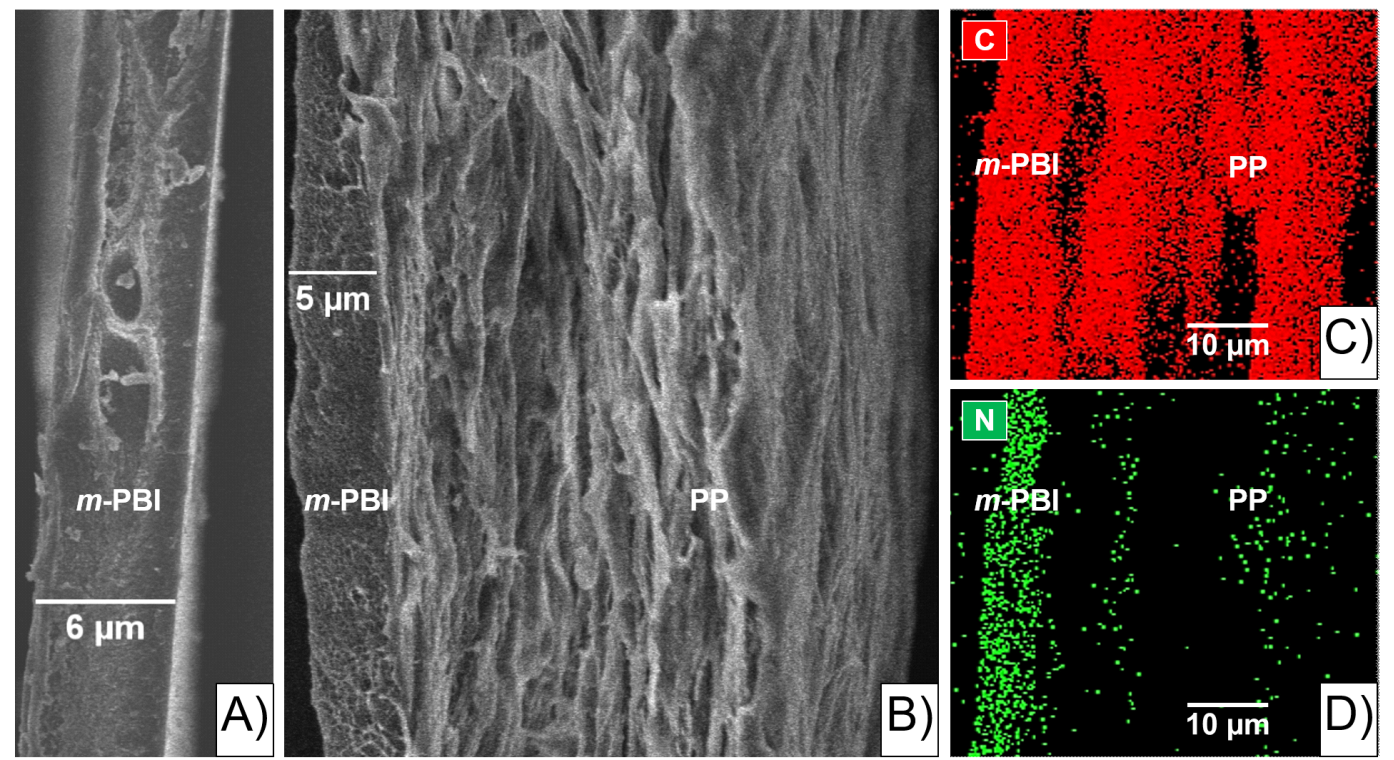

Figure 1. (A) Cross-section SEM image $(30 \mu \mathrm{m}, 6.0 \mathrm{kV}, 2 \mu \mathrm{A}, 9.8 \mathrm{~mm}$ working distance (WD), in lens detector) of the meta-polybenzimidazole ( $m$-PBI) film (6 $\mu \mathrm{m}$ thickness); (B) cross-section SEM image $(20 \mu \mathrm{m}, 6.0 \mathrm{kV}, 2 \mu \mathrm{A}, 9.0 \mathrm{~mm}$ WD, in lens detector) of the polypropylene-polybenzimidazole (PP-PBI) composite asymmetric membrane; (C,D) energy dispersed X-ray (EDX) mapping of the SEM image in (B) for carbon and nitrogen $(10 \mu \mathrm{m}, 6.0 \mathrm{kV}, 2 \mu \mathrm{A}, 9.0 \mathrm{~mm} \mathrm{WD})$.

Subsequently, the polypropylene-polybenzimidazole (abbreviated as PP-PBI) composite asymmetric membrane was prepared through a gluing method by hot-pressing from the thin $m$-PBI $(6 \mu \mathrm{m})$ film and the porous polypropylene (TreoPore ${ }^{\circledR}$ PDA-30, thickness $30 \mu \mathrm{m}$, nonwoven, porosity $>60 \%$, Treofan, Raunheim, Germany) layer. A schematic of the membrane preparation is displayed in Figure 2, alongside a photo of the composite membrane after the hot-pressing treatment. The detailed procedure can be found in Section 4.

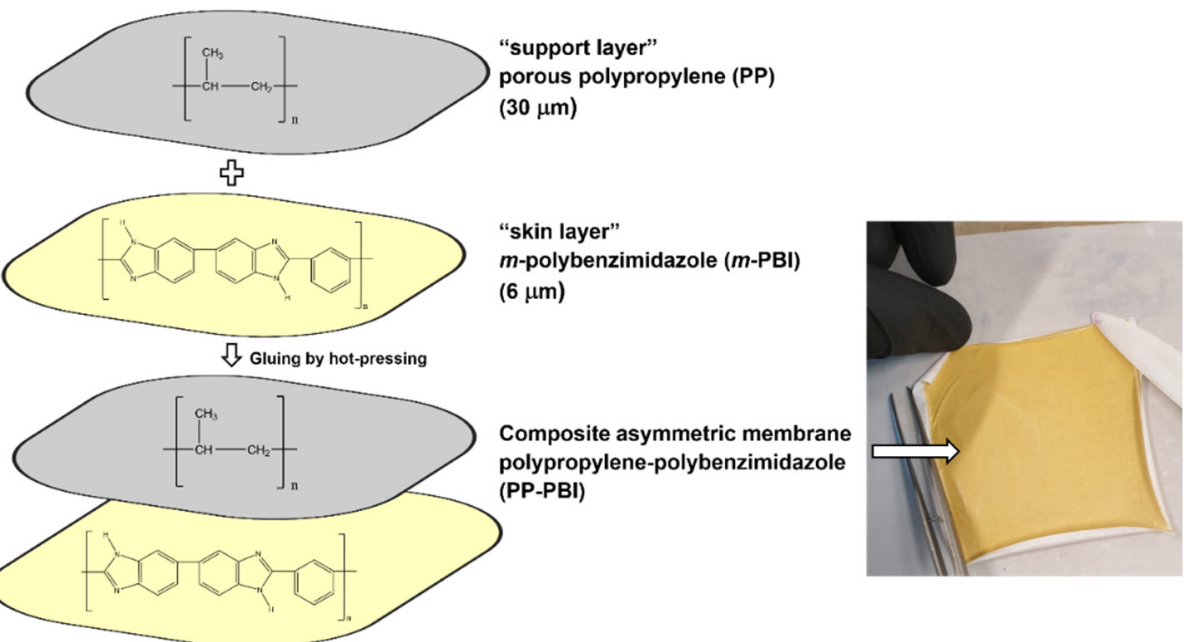

Figure 2. Schematic of the preparation of the asymmetric PP-PBI composite membrane, including a photo of the obtained membrane after hot-pressing.

The SEM image shows the thin $m$-PBI "skin layer" bonded to the porous PP "support layer" (Figure 1B). In particular, the thickness of the $m$-PBI layer looks smaller than before the gluing procedure (Figure $1 \mathrm{~A}$ ), due to the solubilization of the latter into the porous PP 
layer. The area in between the two layers is defined herein as the "interlocking" interface (i.e., interphase). In addition, the energy dispersed X-ray (EDX) analysis qualitatively confirmed $\mathrm{C}$ and $\mathrm{N}$ in the PP-PBI composite membrane as the most significant elements (Figure 1C,D). C was evenly distributed across the sample, while $\mathrm{N}$ was mostly present in and close to the $m$-PBI layer of the membrane configuration.

Later, the diffusion of V(IV) through the composite PP-PBI membrane was measured and compared to that in the commercial NR212 and FAP-450 (Figure 3). A description of the full procedure is reported in Section 4. Both the commercial membranes showed a significant V(IV) diffusion, while the PP-PBI membrane exhibited an almost negligible one.

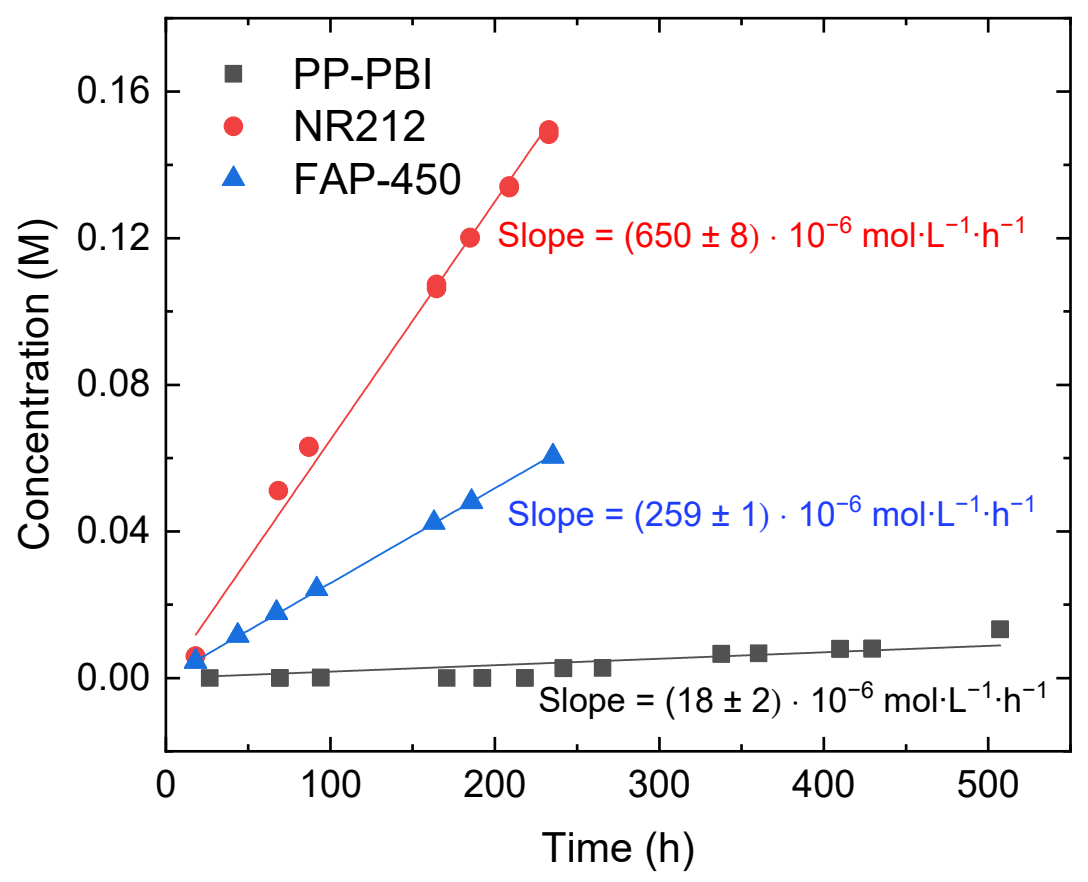

Figure 3. V(IV) diffusion through Nafion ${ }^{\circledR}$ (NR212; red dotted line), Fumasep ${ }^{\circledR}$ (FAP-450; blue dotted line), and PP-PBI (black dotted line).

The experimentally measured values of V(IV) diffusion are reported in Table 1 for all the three membranes.

Table 1. V(IV) diffusion through NR212, FAP-450, and PP-PBI.

\begin{tabular}{ccc}
\hline Name & $\begin{array}{c}\text { Slope [V(IV)] vs. } \boldsymbol{t} \\
\left(\mathbf{M} \cdot \mathbf{L}^{-\mathbf{1}} \cdot \mathbf{h}^{\mathbf{- 1}} \mathbf{)}\right.\end{array}$ & $\begin{array}{c}\mathbf{V}(\mathrm{IV}) \text { Diffusion } \\
\left(\mathbf{c m}^{\mathbf{2}} \cdot \mathbf{m i n}^{\mathbf{- 1}} \mathbf{)}\right.\end{array}$ \\
\hline NR212 & $(650 \pm 8) \times 10^{-6}$ & $(744 \pm 9) \times 10^{-9}$ \\
FAP-450 & $(259 \pm 1) \times 10^{-6}$ & $(351 \pm 1) \times 10^{-9}$ \\
PP-PBI & $(18 \pm 2) \times 10^{-6}$ & $(14 \pm 1) \times 10^{-9}$ \\
\hline
\end{tabular}

Subsequently, the PP-PBI composite membrane was assembled and tested in a VRFB single cell of laboratory scale $\left(25 \mathrm{~cm}^{2}\right)$ (the cell components and the operation procedure, as well as the electrolyte composition, are detailed in Section 4). The cycling performance of NR212 and FAP-450 was evaluated as a comparison to the membrane of the present work. First, the in situ through-plane ohmic area resistance of the cell with the membrane at $-50 \%$ electrolyte state of charge (SOC) (average oxidation state of the vanadium electrolyte equal to 3.5) was measured between $100 \mathrm{kHz}$ and $0.1 \mathrm{~Hz}$ at zero direct current (DC) and a perturbation amplitude of $100 \mathrm{mV}$ by electrochemical impedance spectroscopy (EIS) (Table 2). In the same manner, the cell resistance with only a film of hydrophobic mesoporous PP TreoPore ${ }^{\circledR}$ PDA-30 (thickness $30 \mu \mathrm{m}$, non-woven, porosity $>60 \%$, Treofan, 
Raunheim, Germany) was measured and found equal to $0.35 \Omega \cdot \mathrm{cm}^{2}$. Then, the electrolyte was galvanostatically charged to $100 \%$ SOC by applying $40 \mathrm{~mA} \cdot \mathrm{cm}^{-2}$. During the initial charge, polarization curves were recorded at $20 \%, 30 \%, 50 \%, 70 \%$, and $90 \%$ SOC by consecutively charging and discharging the battery for $20 \mathrm{~s}$ at 20,40, 60, 80, 100, 120, and $200 \mathrm{~mA} \cdot \mathrm{cm}^{-2}$ (Figure 4). Lastly, upon fully charging the battery, five consecutive charge/discharge cycles were performed from $0.80 \mathrm{~V}$ to $1.65 \mathrm{~V}$ as the lower and upper potential limits at a current density of 40, 80,120,160, and $200 \mathrm{~mA} \cdot \mathrm{cm}^{-2}$ (Figure 5). The first cycle at each current density was not included in the analysis as a deviation related to the change in current density could be seen in the data.

Table 2. In situ through-plane ohmic area resistance experimentally measured for the cell with TreoPore ${ }^{\circledR}$ PDA-30, NR212, FAP-450, and PP-PBI.

\begin{tabular}{cc}
\hline Name & $\begin{array}{c}\text { In Situ Through-Plane Ohmic Area } \\
\text { Resistance at } \mathbf{- 5 0 \%}\end{array}$ \\
\hline Electrolyte SOC $\left(\mathbf{\Omega} \cdot \mathbf{c m}^{\mathbf{2}}\right)$
\end{tabular}
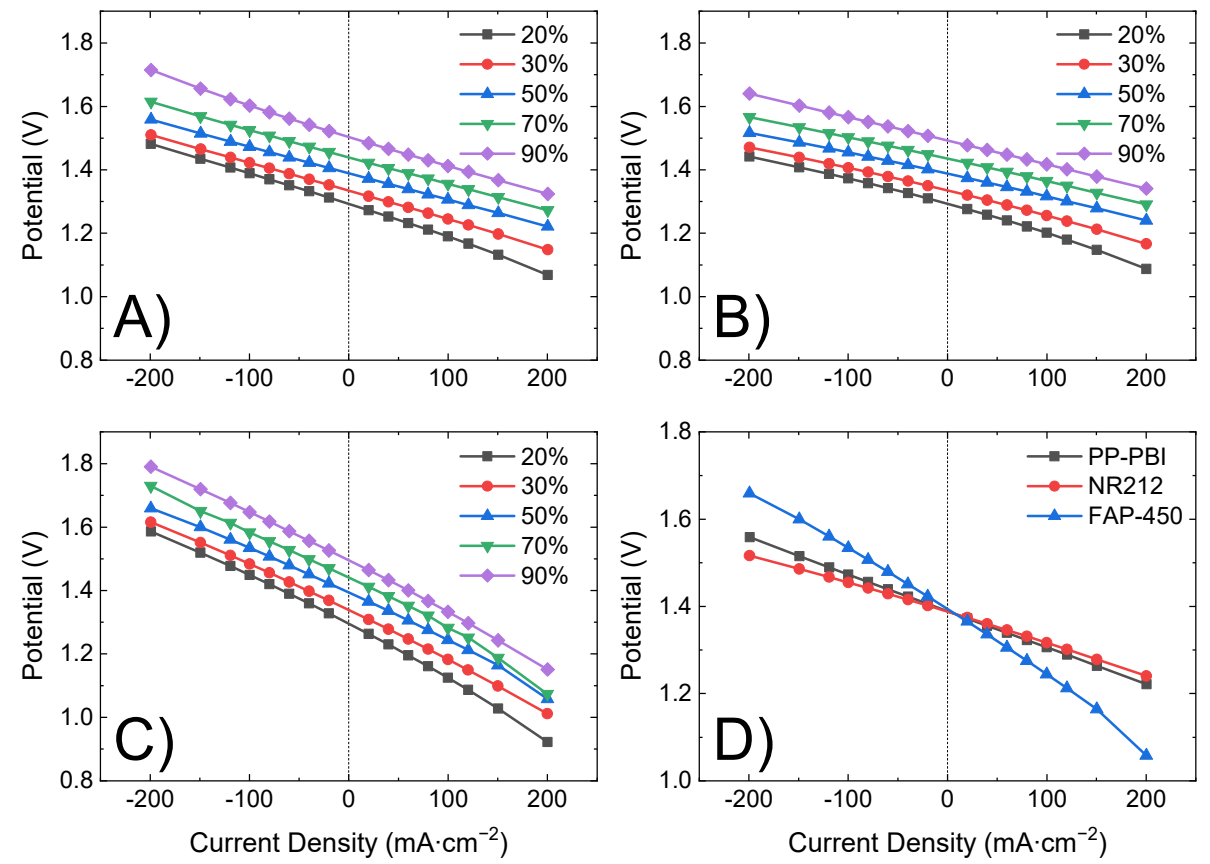

Figure 4. Polarization curves at different electrolyte states of charge (SOCs; $20 \%, 30 \%, 50 \%, 70 \%$, and 90\%) for (A) PP-PBI, (B) NR212, and (C) FAP-450. (D) Comparison of all three membranes at 50\% electrolyte SOC.

The ohmic area resistance of the cell with PP-PBI $\left(0.69 \Omega \cdot \mathrm{cm}^{2}\right)$ was higher than that with commercial NR212 $\left(0.49 \Omega \cdot \mathrm{cm}^{2}\right)$, but lower than that with FAP-450 $\left(1.28 \Omega \cdot \mathrm{cm}^{2}\right)$. The influence of the ohmic resistance was observed in both the polarization curves (Figure 4) and the cycling efficiencies (Figure 5). An increase in the resistance increased the overpotential, thus leading to a steeper polarization curve and to a lower voltaic efficiency and vice versa.

Lastly, the three membranes were galvanostatically cycled at $120 \mathrm{~mA} \cdot \mathrm{cm}^{-2}$ for 90 consecutive cycles, from $0.80 \mathrm{~V}$ to $1.65 \mathrm{~V}$ as the lower and upper potential limits, in $1.6 \mathrm{M} \mathrm{V}$ in $2 \mathrm{M} \mathrm{H}_{2} \mathrm{SO}_{4}$ and $0.05 \mathrm{M} \mathrm{H}_{3} \mathrm{PO}_{4}$ electrolyte (Figure 6). Efficiencies and discharge capacity were calculated according to Equations (5)-(8) in Section 4. The PP-PBI membrane 
showed a good performance (coulombic efficiency $\sim 99 \%$, voltaic efficiency $\sim 84 \%$, and energy efficiency $\sim 84 \%)$. Importantly, this membrane exhibited a high and stable discharge capacity ( $90 \%$ ) over time with a $99 \%$ capacity retention, exceeding those of the commercial NR212 (capacity drop from $90 \%$ to $40 \%$ ) and FAP-450 (capacity drop from $80 \%$ to $65 \%$ ).
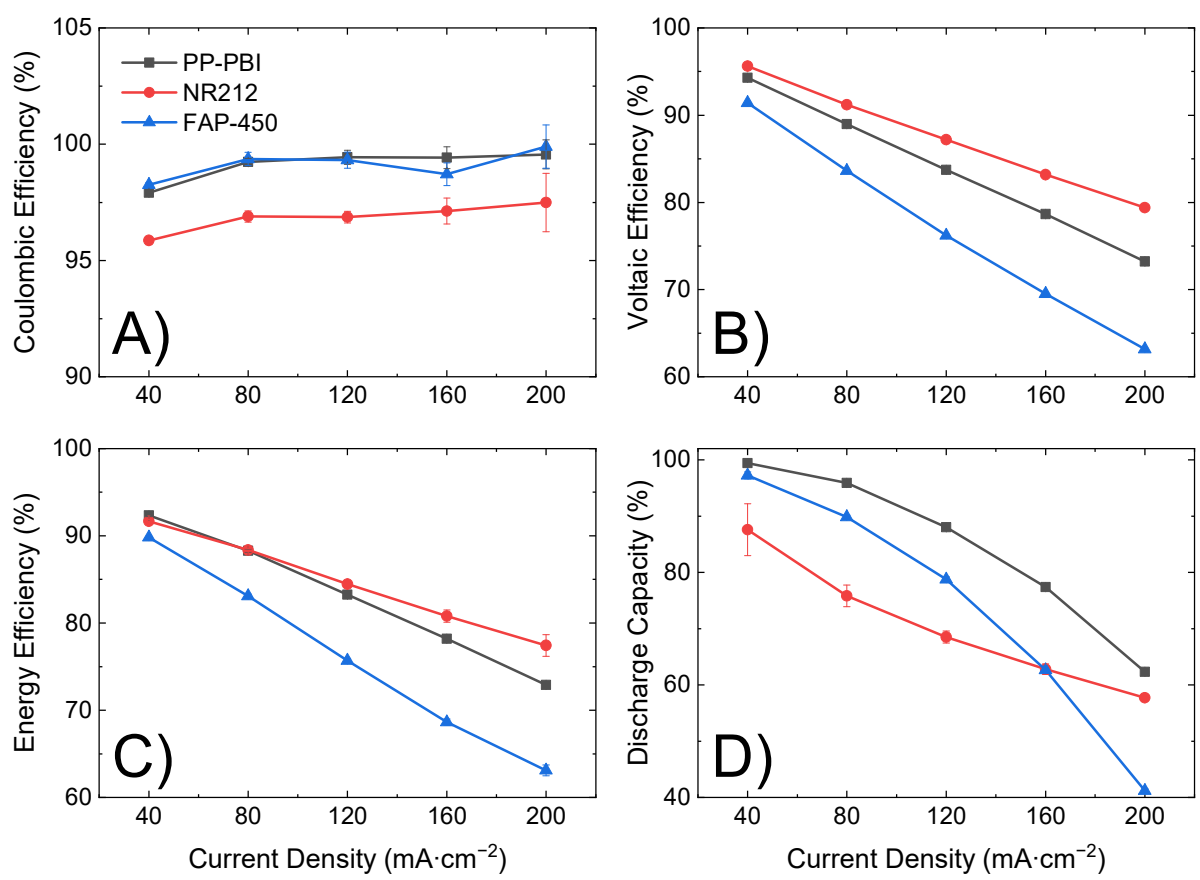

Figure 5. (A-C) Average efficiency over four cycles for NR212 (red line), FAP-450 (blue line), and PP-PBI (black line) at a current density of 40, 80, 120, 160, and $200 \mathrm{~mA} \cdot \mathrm{cm}^{-2}$. (D) Average discharge capacity over four cycles at a current density of $40,80,120,160$, and $200 \mathrm{~mA} \cdot \mathrm{cm}^{-2}$. The error bars represent the standard deviation over four cycles at each current density.
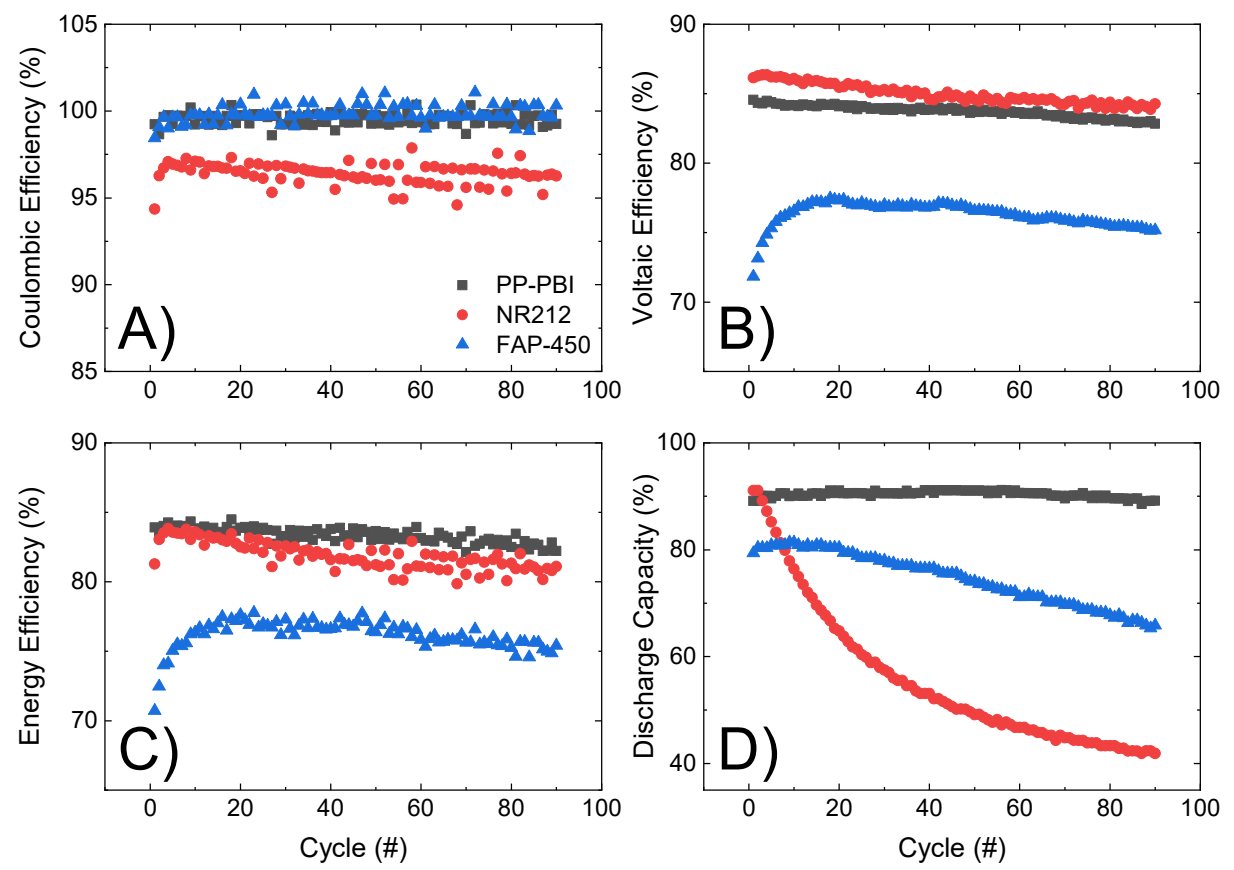

Figure 6. (A-C) Efficiencies of the galvanostatic cycling at $120 \mathrm{~mA} \cdot \mathrm{cm}^{-2}$ for NR212 (red dotted line), FAP-450 (blue dotted line), and PP-PBI (black dotted line). (D) Discharge capacity for the three membranes. Efficiency values exceeding 100\%, likely formed due to the error margin of the measuring equipment (A), are not realistic and should be treated as an efficiency of $100 \%$. 
Importantly, the PP-PBI membrane after the extended galvanostatic cycling in the VRFB revealed no ruptures or delamination of the layers (Figure 7). The SEM image shows the intact $m$-PBI "skin layer" bonded to the PP "support layer" as before the cell testing (see Figure 1B).

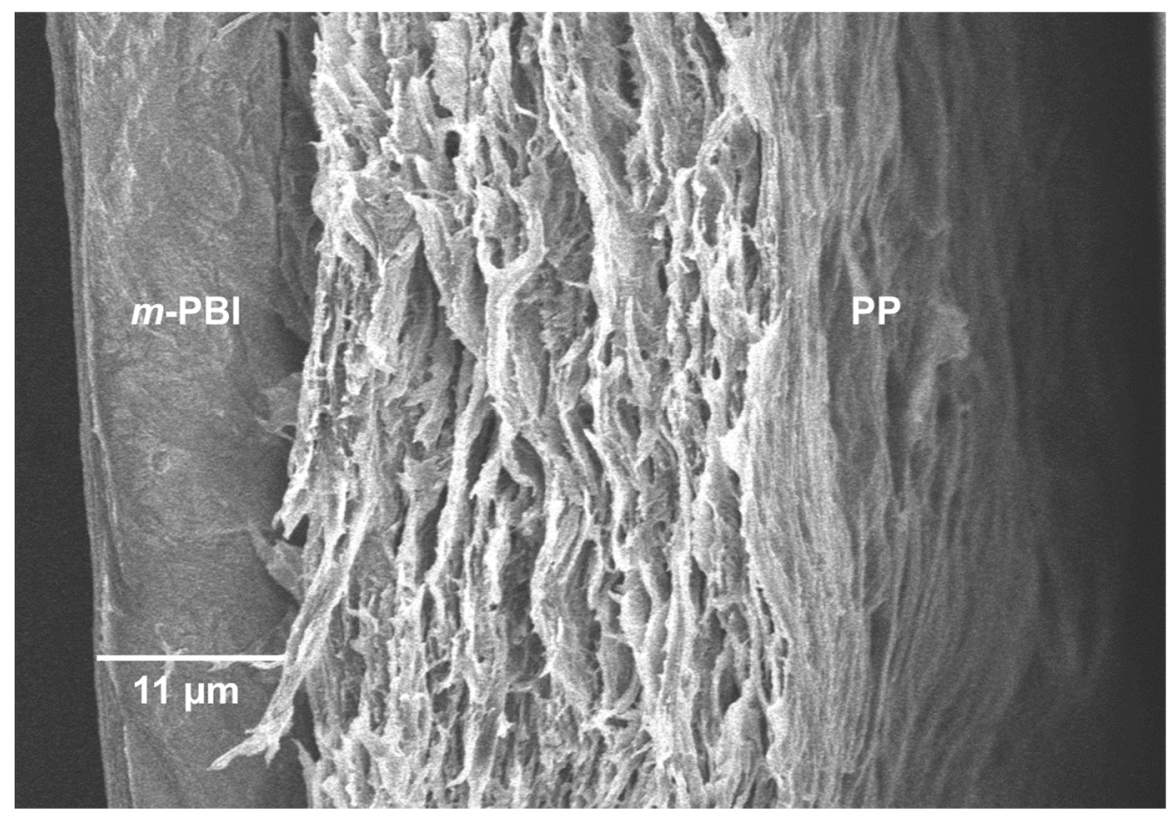

Figure 7. SEM image ( $30 \mu \mathrm{m}, 5.0 \mathrm{kV}, 2 \mu \mathrm{A}, 9.8 \mathrm{~mm}$ WD, in lens detector) of cross-section PP-PBI composite membrane post cell cycling at $120 \mathrm{~mA} \cdot \mathrm{cm}^{-2}$ for 90 cycles.

\section{Discussion}

The asymmetric membrane of this work was made by gluing a thin $m$-PBI $(6 \mu \mathrm{m})$ film to a porous PP $(30 \mu \mathrm{m})$ layer by hot-pressing (see Figure 2$)$. Whereas conventional blade casting of an $m$-PBI solution on a PP support might result in significant seepage of the $m$-PBI polymer into the porous network, resulting in blocked pores and a higher ohmic resistance, the gluing by hot-pressing method minimizes this risk by only partially solubilizing the $m$-PBI skin layer. This partial solubilization of $m$-PBI during the gluing and subsequent hot-pressing to the PP layer results in a particular region of the membrane, herein called the "interlocking" interface (i.e., interphase). Qualitative evidence of this interface was found by SEM, where a slightly thinner $m$-PBI layer $(5 \mu \mathrm{m})$ was interconnected to the porous PP with no visible delamination (Figure 1B). The shrinking of the "skin layer" can be explained by the small quantities of PBI polymer flowing into the support layer (PP), creating the mechanically bonded interface but simultaneously thinning the "skin layer".

The reported data represent the performance of an independently prepared membrane, with each test being conducted a minimum of two times to verify its results.

V(IV) diffusion through the composite PP-PBI membrane was found to be the lowest $\left((14 \pm 1) \times 10^{-9} \mathrm{~cm}^{2} \cdot \mathrm{min}^{-1}\right)$, while commercial Nafion ${ }^{\circledR}$ NR212 suffered the highest $\mathrm{V}(\mathrm{IV})$ diffusion $\left((744 \pm 9) \times 10^{-9} \mathrm{~cm}^{2} \cdot \mathrm{min}^{-1}\right)$, likely due to large negatively charged ionic channels with a diameter of $4-5 \mathrm{~nm}[28,29]$. This is in reasonable agreement with the findings in Oldenburg et al. [30]. Commercial NR212 and Fumasep ${ }^{\circledR}$ FAP-450 showed a steep linear relationship between the concentration of the permeated V(IV) and the time, while the PP-PBI membrane displayed an almost linear trend (Figure 3). The trend of V(IV) diffusion through the PP-PBI membrane was quite peculiar; for the first 9 days of the experiment, no V(IV) diffusion was detected by UV/visible light spectroscopy, which developed to a very slow and stepwise growth until the end of the test. The V(IV) diffusion behavior through the PP-PBI composite membrane was not deeply studied, but it is in reasonable agreement with other works on $m$-PBI based membranes, where no V(IV) 
diffusion could be detected over at least $24 \mathrm{~h}[12,31]$. Importantly, the diffusion of the other $\mathrm{V}$ species needs to be studied to obtain a more comprehensive understanding of the membrane transport properties.

The cell with the PP-PBI membrane showed a slightly higher ohmic area resistance than that with NR212 (0.69 vs. $0.49 \Omega \cdot \mathrm{cm}^{2}$, respectively); however, this value was still significantly lower than that with FAP-450 $\left(1.28 \Omega \cdot \mathrm{cm}^{2}\right)$. The influence of this slight increase in ohmic area resistance vs. NR212 can be seen in the polarization curves and in the voltaic efficiency of the PP-PBI membrane, as it led to an increase in the ohmic overpotential $\left(\eta_{\mathrm{ohm}}\right)$, steepening the polarization curve and lowering the voltaic efficiency. A similar trend, but to a more extreme extent, could be seen for FAP-450.

The PP-PBI membrane cycled at different current densities showed relatively good efficiencies (from $>90 \%$ at the lowest current density of $40 \mathrm{~mA} \cdot \mathrm{cm}^{-2}$ to $\sim 75 \%$ at the highest current density of $200 \mathrm{~mA} \cdot \mathrm{cm}^{-2}$ ) (Figure $5 \mathrm{~A}-\mathrm{C}$ ). Then, when charged/discharged at $120 \mathrm{~mA} \cdot \mathrm{cm}^{-2}$ for 90 consecutive cycles, it exceeded the performance of the commercial NR212 and FAP-450. In particular, it showed the greatest discharge capacity $(\sim 90 \%)$ with a $99 \%$ capacity retention. The investigation of such a stable performance in a VRFB from the PP-PBI membrane is currently in progress; however, at this stage, it is believed that the asymmetric configuration with a relatively thin $m$-PBI film supported on a porous PP layer could be a benefit. Another aspect worth mentioning related to this prolonged cycling test in the VRFB involved the thickness of the $m$-PBI film and the applied current density. In a recent study, Oldenburg et al. [22] demonstrated how the net $\mathrm{V}$ flux in an amphoteric PBI/Nafion bilayer membrane for VRFBs shifted to the positive side of the system by increasing the current density. Because of this shift, a thicker PBI layer $(>4 \mu \mathrm{m})$ was needed to balance the net $\mathrm{V}$ flux. This study is in good agreement with the present work, where the thickness of the $m$-PBI film $(6 \mu \mathrm{m})$ and the applied current density yielded a very low net $\mathrm{V}$ flux.

Lastly, the SEM characterization post cycling test qualitatively showed no delamination of the layers or ruptures in the membrane structure. Interestingly, the SEM characterization revealed a thicker $m$-PBI film $(11 \mu \mathrm{m})$ than before the cycling in the VRFB $(5 \mu \mathrm{m})$. This phenomenon can be attributed to the swelling of the composite membrane in the electrolyte during the extended cycling. In fact, EDX analysis confirmed the presence of $\mathrm{S}$ coming from the $\mathrm{H}_{2} \mathrm{SO}_{4}$ contained in the electrolyte, likely retained in the membrane structure despite several washing steps in Milli-Q water.

Despite the excellent performance in an electrochemical cell, low cost with respect to membranes of the Nafion ${ }^{\circledR}$ type, and good adhesion between the "skin" and "support" layer of the prepared PP-PBI membrane, it has to be mentioned that membranes prepared from $m$-PBI are required to be thin, due to their lower conductivity, to compete with the performance of Nafion ${ }^{\circledR}$ type membranes. As such, further research on improving the conductivity of $m$-PBI, for example, through functionalization of the imidazole group, is desired to further enhance the performance of the membrane and, thus, improve its applicability.

\section{Materials and Methods}

\subsection{Preparation of the $m-P B I$}

$m$-Polybenzimidazole (abbreviated as $m$-PBI) was synthesized by Blue World Technologies (BWT) from 3,3'-diaminobenzidine and isophthalic acid at a 1:1 molar ratio by polymerization in polyphosphoric acid (PPA) at $180-250{ }^{\circ} \mathrm{C}$ under $\mathrm{N}_{2}$ for $2 \mathrm{~h}$ according to a procedure by Li et al. [32]. For more details on the so-called PPA process, the reader is referred to $[33,34]$. This specific temperature range refers to the initial synthesis temperature $\left(180^{\circ} \mathrm{C}\right)$, corresponding to the addition of the PPA, with $250^{\circ} \mathrm{C}$ as the used and maximum synthesis temperature to avoid ending up with a higher molecular weight. The prepared polymer solution was poured into a water bath to obtain PBI fibers. It was neutralized by addition of a $\mathrm{NaOH}$ solution, washed with distilled water, and dried in an oven at $120^{\circ} \mathrm{C}$. 
The obtained PBI powder was dissolved in N,N-dimethylacetamide (DMAc) (10\% $\mathrm{PBI}$ in DMAc) at room temperature and then heated to $100{ }^{\circ} \mathrm{C}$ under continuous stirring for $12 \mathrm{~h}$. The membrane was prepared by casting the PBI solution onto a glass plate and allowing the solvent to evaporate slowly in a temperature range from 40 to $120^{\circ} \mathrm{C}$ with a step rate of $10^{\circ} \mathrm{C} \cdot \mathrm{h}^{-1}$. The membranes were then washed with distilled water at $80{ }^{\circ} \mathrm{C}$. Lastly, the film was dried at $130{ }^{\circ} \mathrm{C}$ for $2 \mathrm{~h}$.

\subsection{Characterization of the $m-P B I$}

Inherent viscosity measurements were conducted using a capillary viscometer (SI Analytics Glass Kinematic Ubbelohde viscometer 501 13/Ic, Mainz, Germany) at a concentration of $0.5 \mathrm{~g} \cdot 100 \mathrm{~mL}^{-1} \mathrm{PBI}$ in sulfuric acid $96 \%$ at $30{ }^{\circ} \mathrm{C}$.

NMR spectroscopy in DMSO- $\mathrm{d}_{6}$ was performed using a Bruker Ascend $400 \mathrm{MHz}$ NMR spectrometer (Billerica, MA, USA).

Transmittance Fourier-transform infrared spectroscopy was carried out on pristine and acid-doped $m$-PBI films with the help of a Bruker Vertex V70 spectrometer (Billerica, MA, USA). Before analyzing the $m$-PBI samples $(2.0 \times 3.0 \mathrm{~cm}, 6 \mu \mathrm{m})$, they were dried at $60{ }^{\circ} \mathrm{C}$ under vacuum for $2 \mathrm{~h}$ to remove residual water in the polymer. For the acid-doped $m$-PBI, before drying, the samples were placed in a $2 \mathrm{M} \mathrm{H}_{2} \mathrm{SO}_{4}$ solution for $18 \mathrm{~h}$ and subsequently dipped five times in deionized water to remove any $\mathrm{H}_{2} \mathrm{SO}_{4}$ present on the surface of the polymeric film.

To study the thermal stability of the membranes, TGA/DTA was conducted using a TGA 550 (TA instruments Inc., New Castle, DE, USA) with a heating rate of $10^{\circ} \mathrm{C} \cdot \mathrm{min}^{-1}$ from room temperature to $950{ }^{\circ} \mathrm{C}$.

The chemical stability of the $m$-PBI layer (ex situ) was investigated by immersing a PBI membrane piece $(3 \times 3 \mathrm{~cm})$ for 4 months in $50 \mathrm{~mL}$ of vanadium solution $(1.6 \mathrm{M} \mathrm{V}(\mathrm{V}))$ in $2.0 \mathrm{M} \mathrm{H}_{2} \mathrm{SO}_{4}$ and $0.05 \mathrm{M} \mathrm{H}_{3} \mathrm{PO}_{4}$, obtained by charging the electrolyte solution $\mathrm{V}(\mathrm{IV}): \mathrm{V}$ (III) (50:50) from Oxkem (Reading, UK) in a VRFB cell (catholyte), at room temperature.

\subsection{Preparation of PP-PBI Composite Asymmetric Membrane}

A meta-polybenzimidazole film $(m-\mathrm{PBI}, 6.5 \times 6.5 \mathrm{~cm}$, thickness $6 \mu \mathrm{m})$, prepared as described in Section 4.1, was placed on a polytetrafluoroethylene sheet (PTFE, $15.5 \times 15.5 \mathrm{~cm}$, $200 \mu \mathrm{m}$ thickness, Itin Technik GmbH, Twann, Switzerland) and covered by a microporous polypropylene separator (PP, TreoPore ${ }^{\circledR}$ PDA-30, $7.0 \times 7.0 \mathrm{~cm}$, thickness $30 \mu \mathrm{m}$, porosity $>60 \%$, Treofan, Raunheim, Germany). Then, using Kimwipe ${ }^{\circledR}$ disposable wipers (Kimberly-Clark Professional, Koblenz, Germany), the PP separator was wetted by a gluing solution comprising dimethylacetamide (DMAc, 99\%, Alfa Aesar, Kandel, Germany) in isopropanol (IPA, 99.5\%, Carl Roth, Karlsruhe, Germany) with a volume ratio of 1:2. Simultaneously, air between the layers was removed until the underlying $m$-PBI layer was seen clearly. Subsequently, the excess of solvent was removed and the stack was completed by placing two regular tissues $(10.5 \times 10.5 \mathrm{~cm})$ and a PTFE sheet $(15.5 \times 15.5 \mathrm{~cm}, 200 \mu \mathrm{m}$ thickness, Itin Technik GmbH, Twann, Switzerland) on top of the PP film. The stack was hot-pressed at $80{ }^{\circ} \mathrm{C}$ with a force of 2.5 tons for $15 \mathrm{~min}$. Lastly, the hot-pressed composite membrane was placed in a vacuum oven (Gallenkamp, Loughborough, UK) at $100{ }^{\circ} \mathrm{C}$ for $45 \mathrm{~min}$ and then in IPA for $1 \mathrm{~h}$. The resulting composite membrane was then ready for further tests or characterization measures without any additional pretreatment.

\subsection{Scanning Electron Microscopy (SEM) and Energy Dispersed X-ray (EDX) Analysis}

Scanning electron microscopy (SEM) cross-sections of thin pristine $m$-PBI ( $6 \mu \mathrm{m}$ thickness) and the corresponding composite PP-PBI membrane were prepared using a liquid nitrogen breaking method. First, the specimen $(0.5 \times 2.0 \mathrm{~cm})$ was wetted in IPA and then immersed in liquid nitrogen for approximately $20 \mathrm{~s}$ with the help of a pair of tweezers. Next, the sample was broken into two pieces and the cross-sections were placed face up in a slotted specimen stub (12 mm diameter, Agar Scientific, Stansted, UK). Lastly, the SEM 
samples were sputter-coated with a $10 \mathrm{~nm}$ layer of chromium using a LEICA EM ACE600 coater (Leica Microsystems, Heerbrugg, Switzerland).

SEM images of the thin $m$-PBI layer ( $6 \mu \mathrm{m}$ thickness) and of the prepared composite PP-PBI membrane cross-section samples before and after cycling tests in the VRFB were obtained using a Hitachi Regulus 8230 series high-resolution scanning electron microscope (Tokyo, Japan), equipped with an energy dispersed X-ray analysis (EDX) detector. Experimental conditions of $6.0 \mathrm{kV}$ accelerating voltage and 2 to $3 \mu \mathrm{A}$ current were used for both electron imaging and EDX analysis. Secondary electron (SE) images were recorded with an in lens detector at a working distance (WD) of 8 to $9 \mathrm{~mm}$ depending on the sample. The built-in software "Hitachi Regulus" was used for SEM imaging and the software "Oxford-Aztec 3.3" was used for EDX analysis.

\subsection{Vanadium RFB Relevant Membrane Properties}

\subsubsection{Water and Electrolyte Uptake}

Water and electrolyte uptake was determined for the following materials: (i) $m$-PBI $\left(2.0 \times 4.0 \mathrm{~cm}, 39 \mu \mathrm{m}\right.$ thickness, Blue World Technologies, Kvistgård, Denmark), (ii) Fumasep ${ }^{\circledR}$ FAP-450 (2.0 $\times 4.0 \mathrm{~cm}$, Fumatech BWT Group, Bietigheim-Bissingen, Germany), and (iii) Nafion ${ }^{\circledR}$ NR212 $(2.0 \times 4.0 \mathrm{~cm}$, Ion Power, New Castle, DE, USA).

The dry weight of the membrane $\left(m_{d r y}\right)$ was obtained after drying it under vacuum at $55^{\circ} \mathrm{C}$ for $22 \mathrm{~h}$. The weight measurement was carried out in a closed vial to limit the uptake of moisture from the air. Then, the weight of the membrane in the wet state $\left(m_{\text {wet }}\right)$ was determined after immersion for 2 days in deionized water or in $1.6 \mathrm{M}$ vanadium in $2 \mathrm{M}$ $\mathrm{H}_{2} \mathrm{SO}_{4}$ and $0.05 \mathrm{M} \mathrm{H}_{3} \mathrm{PO}_{4}$ electrolyte (SOC $-50 \%$, 3.5 oxidation state, Oxkem, Reading, $\mathrm{UK}$ ), followed by the removal of droplets on the surface with a tissue. In this case, the wet weight was measured in a vial to reduce the evaporation of water from the membrane. Lastly, water and electrolyte uptake of pristine $m$-PBI and of commercial membranes NR212 and FAP-450 was calculated according to Equation (1).

$$
\text { Uptake }=\frac{m_{\text {wet }}-m_{d r y}}{m_{d r y}} \cdot 100 \%
$$

\subsubsection{In-Plane Conductivity}

The in-plane conductivity in $1.6 \mathrm{M}$ vanadium in $2 \mathrm{M} \mathrm{H}_{2} \mathrm{SO}_{4}$ and $0.05 \mathrm{M} \mathrm{H}_{3} \mathrm{PO}_{4}$ vanadium electrolyte (SOC $-50 \%, 3.5$ oxidation state, Oxkem, Reading, UK) was determined for (i) $m$-PBI (4.0 $\times 5.0 \mathrm{~cm}, 39 \mu \mathrm{m}$ thickness, Blue World Technologies, Kvistgård, Denmark), (ii) Fumasep ${ }^{\circledR}$ FAP-450 $(4.0 \times 5.0 \mathrm{~cm}$, Fumatech BWT Group, Bietigheim-Bissingen, Germany), and (iii) Nafion ${ }^{\circledR}$ NR212 $(4.0 \times 5.0 \mathrm{~cm}$, Ion Power, New Castle, DE, USA). All membranes were immersed in the electrolyte for 2 days. Then, samples with a size of $1.2 \times 3.0 \mathrm{~cm}$ were punched out. These were immersed again in the electrolyte for another $2 \mathrm{~h}$. Subsequently, the membrane thickness was measured using a thickness gauge (Heidehain MT12B, Measurement Technologies \& Supply Inc, St. Clair Shores, MI, USA) and the resistance was recorded in air using a four-point probe setup (Bekktech BT-112 cell, Scribner, Southern Pines, NC, USA, and LCR-6100, Gw Instek, New Taipei City, Taiwan, LCR meter). Lastly, the in-plane conductivity ( $\sigma$ in $\mathrm{mS} \cdot \mathrm{cm}^{-1}$ ) was calculated according to Equation (2), where $l$ is the distance between the sense probes in $\mathrm{mm}, R$ is the measured resistance in $\mathrm{k} \Omega$, $w_{\text {sample }}$ is the width of the sample in $\mathrm{cm}$, and $t_{\text {wet }}$ is the wet thickness in $\mu \mathrm{m}$.

$$
\sigma=\frac{l}{R \cdot w_{\text {sample }} \cdot t_{\text {wet }}}
$$

\subsubsection{V(IV) Diffusion}

Diffusion of vanadium(IV) through the membrane was determined in a home-built cell (Figure S5, Supplementary Materials). The flasks were filled on one side with $150 \mathrm{~mL}$ of $1.6 \mathrm{M} \mathrm{VOSO}_{4}\left(>95 \% \mathrm{VOSO}_{4} \cdot 5 \mathrm{H}_{2} \mathrm{O}\right.$, Thermo Fisher Scientific, Reinach, Switzerland $)$ in $2 \mathrm{M}$ 
$\mathrm{H}_{2} \mathrm{SO}_{4}$ and on the other side with $150 \mathrm{~mL}$ of $1.6 \mathrm{M}$ magnesium sulfate $\left(\mathrm{MgSO}_{4}\right.$, anhydrous, Reagent Plus ${ }^{\circledR}, \geq 99.5 \%$, Sigma-Aldrich, Buchs, Switzerland) in $2 \mathrm{M} \mathrm{H}_{2} \mathrm{SO}_{4}$ as the enriched and deficient compartments, respectively. Each compartment was continuously stirred to avoid any deviations in concentration. This test was carried out for (i) the PP-PBI membrane of the present work $(5.0 \times 5.0 \mathrm{~cm}$, comprising of a $6 \mu \mathrm{m} \mathrm{m}$-PBI layer and a $30 \mu \mathrm{m}$ PP layer), (ii) Fumasep ${ }^{\circledR}$ FAP-450 $(5.0 \times 5.0 \mathrm{~cm}$, Fumatech BWT Group, Bietigheim-Bissingen, Germany), and (iii) Nafion ${ }^{\circledR}$ NR212 $(5.0 \times 5.0 \mathrm{~cm}$, Ion Power, New Castle, DE, USA). For each membrane, the permeability test lasted a minimum of $220 \mathrm{~h}$. During this period, $\mathrm{UV} /$ visible light measurements between $200 \mathrm{~nm}$ and $800 \mathrm{~nm}$ were performed, from which the $\mathrm{VOSO}_{4}$ absorbance peak at $765 \mathrm{~nm}$ was used to calculate the $\mathrm{VOSO}_{4}$ concentration. The measurements were carried out by filling two quartz cuvettes (Hellma Analytics, Zumikon, Switzerland) with $2.5 \mathrm{~mL}$ of solution from the $\mathrm{MgSO}_{4}$ flask. Each time, the measured solution was transferred back to the $\mathrm{MgSO}_{4}$ flask to avoid significant volume changes. In the case of NR212, after 4 days, the samples were diluted five times to ensure that an absorbance of 1.2 was not exceeded. Therefore, $0.5 \mathrm{~mL}$ from the receiving flask was diluted with $2 \mathrm{~mL}$ of $1.6 \mathrm{M} \mathrm{MgSO}_{4}$ in $2 \mathrm{M} \mathrm{H}_{2} \mathrm{SO}_{4}$ to prepare the measurement solutions, and $0.5 \mathrm{~mL}$ was removed from the enriched compartment to minimize hydrostatic pressure effects.

The $\mathrm{VOSO}_{4}$ diffusion through the membrane (abbreviated as $D_{V O S O 4}$ in $\mathrm{cm}^{2} \cdot \mathrm{min}^{-1}$ in Equation (3)) was calculated according to the Fick's Law [31,35]. $V_{D}$ is the solution volume in the $\mathrm{MgSO}_{4}$ flask (in mL), $A$ is the exposed area of the membrane $\left(7.07 \mathrm{~cm}^{2}\right), L$ is the thickness of the membrane in the swollen state (in cm), $C_{E}$ is the $\mathrm{VOSO}_{4}$ concentration in the enriched compartment (in M), and $C_{D}$ is the measured $\mathrm{VOSO}_{4}$ concentration in the deficient compartment (in M). $C_{D}$ at a given time was obtained by a linear regression analysis on the measured $\mathrm{VOSO}_{4}$ concentration in the deficient compartment.

$$
V_{D} \cdot \frac{d\left(C_{D}(t)\right)}{d t}=A \cdot \frac{D_{V O S O 4}}{L}\left(C_{E}-C_{D}(t)\right)
$$

\subsubsection{Oxidative Stability via "Accelerated Stress Test (AST)"}

According to a procedure from Oldenburg et al. [36], the oxidative stability was assessed for the following materials: (i) $m$-PBI $(2.0 \times 4.0 \mathrm{~cm}, 39 \mu \mathrm{m}$ thickness, Blue World Technologies, Kvistgård, Denmark), (ii) Fumasep ${ }^{\circledR}$ FAP-450 $(2.0 \times 4.0 \mathrm{~cm}, 50 \mu \mathrm{m}$ thickness, Fumatech BWT Group, Bietigheim-Bissingen, Germany), and (iii) Nafion ${ }^{\circledR}$ NR212 $(2.0 \times 4.0 \mathrm{~cm}, 51 \mu \mathrm{m}$ thickness, Ion Power, New Castle, DE, USA). A solution of $0.2 \mathrm{M}$ cerium sulfate ( $\mathrm{Ce}\left(\mathrm{SO}_{4}\right)_{2} 99 \%$, Acros Organics, Geel, Belgium) in $2 \mathrm{M} \mathrm{H}_{2} \mathrm{SO}_{4}$ at $80{ }^{\circ} \mathrm{C}$ was used as agent for the AST. The initial weight of each membrane was measured before starting the test, which lasted for 7 days. Then, the membranes were washed in $2 \mathrm{M}$ $\mathrm{H}_{2} \mathrm{SO}_{4}$ and deionized water to remove any residual of $\mathrm{Ce}\left(\mathrm{SO}_{4}\right)_{2}$ and $\mathrm{H}_{2} \mathrm{SO}_{4}$, respectively. Subsequently, they were dried in vacuum at $55^{\circ} \mathrm{C}$ for $8 \mathrm{~h}$, after which their weight was measured again. Lastly, the change in weight $(\Delta m)$ was calculated according to Equation (4). In Equation (4), $m_{i}$ and $m_{f}$ are the initial and final weight, respectively.

$$
\Delta m=\frac{m_{f}-m_{i}}{m_{i}} \cdot 100 \%
$$

\subsection{Cell Operation and Galvanostatic Cycling Tests}

All membranes, i.e., (i) Nafion ${ }^{\circledR}$ NR212 $(51 \mu$ m dry thickness, Ion Power, New Castle, DE, USA), (ii) Fumasep ${ }^{\circledR}$ FAP-450 (50 $\mu$ m dry thickness, Fumatech BWT Group, BietigheimBissingen, Germany), and (iii) PP-PBI (comprising of a $6 \mu \mathrm{m} m$-PBI layer and a $30 \mu \mathrm{m}$ PP layer), were tested in a laboratory electrochemical cell with an active area of $25 \mathrm{~cm}^{2}$ using an electrochemical test station (Scribner Model 857 test stand, Scribner Associates, Southern Pines, NC, USA), equipped with in-house designed glass tanks and a multichannel peristaltic pump (Masterflex L/S ${ }^{\circledR}$, GZ-07522-20, Cole-Parmer GmbH, Wertheim, Germany) with plasticizer-free chemical resistant tubing (Versilon ${ }^{\mathrm{TM}}$ 2001, GZ-06475-16, Cole-Parmer $\mathrm{GmbH}$, Wertheim, Germany). All data were analyzed using Flowcell ${ }^{\mathrm{TM}}$ software (Scribner 
Associates, Southern Pines, NC, USA) and BView (Scribner Associates, Southern Pines, NC, USA). Prior to assembly in the electrochemical cell, NR212 and FAP-450 membranes were wetted in deionized water, whereas the PP-PBI composite membrane was wetted in IPA due to the hydrophobic nature of the PP support. The PP-PBI membrane was mounted into the electrochemical cell with the $m$-PBI layer facing the negative-side electrolyte and the PP layer facing the positive-side electrolyte.

The electrochemical cell was assembled with (i) two triple-serpentine graphite flow fields (Scribner Associates, Southern Pines, NC, USA), (ii) two gold-plated copper current collectors (Scribner Associates, Southern Pines, NC, USA), (iii) two pre-treated carbon felt electrodes, used as received ( $25 \mathrm{~cm}^{2}$ active area, AAF304ZS, Toyobo, Osaka, Japan), and (iv) two in-house designed polyvinylidene fluoride (PVDF) gasket frames $(7.6 \times 7.6 \mathrm{~cm}$, $2 \mathrm{~mm}$ thickness negative side, $3 \mathrm{~mm}$ thickness positive side). The eight bolts of the electrochemical cell were tightened to $4 \mathrm{~N} \cdot \mathrm{m}$, with the thickness of the gaskets leading to an average carbon felt electrode compression of $42 \%$.

Next, $1.6 \mathrm{M}$ vanadium in $2 \mathrm{M} \mathrm{H}_{2} \mathrm{SO}_{4}$ and $0.05 \mathrm{M} \mathrm{H}_{3} \mathrm{PO}_{4}$ electrolyte $(40 \mathrm{~mL}$ for each tank, state of charge of $-50 \%$, Oxkem, Reading, UK), constantly purged with argon $\left(5 \mathrm{~mL} \cdot \mathrm{min}^{-1}\right)$, was used for all cell experiments at an experimentally measured flow rate of $60 \mathrm{~mL} \cdot \mathrm{min}^{-1}$.

Prior to cycling, the membrane and electrode in the electrochemical cell were conditioned under electrolyte flow (3.5 oxidation state) without any applied current for a period of $4 \mathrm{~h}$. Galvanostatic cycling tests were performed between $0.80 \mathrm{~V}$ and $1.65 \mathrm{~V}$ as the lower and upper potential limits, respectively. First, the in situ through-plane ohmic area resistance of the cell with the membrane at $-50 \%$ electrolyte state of charge (SOC) was measured between $100 \mathrm{kHz}$ and $0.1 \mathrm{~Hz}$ at zero DC and a perturbation amplitude of $100 \mathrm{mV}$ by electrochemical impedance spectroscopy (EIS). In the same manner, the cell resistance with only TreoPore ${ }^{\circledR}$ PDA-30 was measured. Subsequently, the RFB was charged to $100 \%$ SOC at a constant current density of $40 \mathrm{~mA} \cdot \mathrm{cm}^{-2}$. During the initial charge, polarization curves were recorded at a SOC of $20 \%, 30 \%, 50 \%, 70 \%$, and $90 \%$ by consecutively charging and discharging for $20 \mathrm{~s}$ at a current density of 20,40,60, 80, 100, 120,150 , and $200 \mathrm{~mA} \cdot \mathrm{cm}^{-2}$. Upon fully charging, five consecutive charge/discharge cycles were performed at $40,80,120,160$, and $200 \mathrm{~mA} \cdot \mathrm{cm}^{-2}$. The first cycle at each current density was not included in the analysis as deviations related to the change in current density could be seen in the data.

Efficiencies and discharge capacity are calculated according to the Equations (5)-(8). In Equations (5)-(7), $Q_{c h}$ and $Q_{d i s}$ are the charges for the discharge and the charge process, while $\bar{U}_{c h}$ and $\bar{U}_{d i s}$ are the average voltages during charge and discharge, respectively. In Equation (8), $Q_{\text {theoretical }}$ is the theoretical charge, $n$ is the number of moles, $F$ is the Faraday constant $\left(96,485 \mathrm{C} \cdot \mathrm{mol}^{-1}\right)$, and $z$ the number of electrons associated with the electrochemical reaction.

$$
\begin{gathered}
\eta_{C}=\frac{Q_{d i s}}{Q_{c h}} \cdot 100 \% \\
\eta_{V}=\frac{\bar{U}_{d i s}}{\bar{U}_{c h}} \cdot 100 \% \\
\eta_{E}=\left(\eta_{C} \cdot \eta_{V}\right) \cdot 100 \% \\
Q_{\text {theoretical }}=I \cdot t=n \cdot(F \cdot z)
\end{gathered}
$$

\section{Conclusions}

The present work demonstrated a composite membrane for VRFBs and a method of preparation. This membrane has an asymmetric configuration with two layers: an $m$-PBI layer $(6 \mu \mathrm{m})$ and a porous PP layer $(30 \mu \mathrm{m})$, bonded in an "interlocking" interface, obtained via a gluing procedure by hot-pressing. The $m$-PBI film, known for its stable chemical structure, is able to mitigate $\mathrm{V}$ crossover due to its AEM properties in acidic conditions. This asymmetric composite membrane showed the lowest V(IV) diffu- 
sivity $\left((14 \pm 1) \times 10^{-9} \mathrm{~cm}^{2} \cdot \mathrm{min}^{-1}\right)$ as compared to the commercial Nafion ${ }^{\circledR} \mathrm{NR} 212$ and Fumasep ${ }^{\circledR}$ FAP-450, $(744 \pm 9) \times 10^{-9}$ and $(351 \pm 1) \times 10^{-9} \mathrm{~cm}^{2} \cdot \mathrm{min}^{-1}$, respectively. Furthermore, out of these three membranes, the PP-PBI membrane exhibited the highest energy efficiency $(\sim 84 \%)$, discharge capacity $(\sim 90 \%)$, and capacity retention $(99 \%)$ when galvanostatically charged/discharged over 90 cycles at $120 \mathrm{~mA} \cdot \mathrm{cm}^{-2}$, making this membrane a promising candidate for the next generation of membranes for RFBs. Nevertheless, more research is required to further enhance the energy efficiency at high current densities by increasing the conductivity or reducing the resistance of the membrane, while maintaining an equal or better capacity retention.

\section{Patents}

J. C. Duburg, A. Schneider, E. Zanzola and L. Gubler, "Method for laminating a polymer electrolyte film onto a porous support layer for energy storage devices", Paul Scherrer Institute, Switzerland, application no. EP20215599.0, submission date 18 December 2020.

Supplementary Materials: Figure S1: ${ }^{1} \mathrm{H}-\mathrm{NMR}$ spectrum of $m$-PBI powder in DMSO-d $\mathrm{d}_{6}$, Figure S2: TGA/DTA analysis on the $m$-PBI film, Figure S3: FTIR of the pristine and the acid doped $m$-PBI film. The characteristic peaks were assigned according to [37-39], Figure S4: Calibration plot of $\mathrm{VOSO}_{4}$ in $2 \mathrm{M} \mathrm{H}_{2} \mathrm{SO}_{4}$, Figure S5: Photo of the "home-built" diffusion cell for testing the V(IV) diffusion through the membranes (NR212, FAP-450 and PP-PBI), Figure S6: EDX map of the PP-PBI membrane after 90 consecutive galvanostatic cycles in the VRFB at $120 \mathrm{~mA} \cdot \mathrm{cm}^{-2}$, Figure S7: Cell components of the VRFB setup used in the present work, Figure S8: Photos of the ex situ stability test of the $m$-PBI membrane in $\mathrm{V}(\mathrm{V})$ electrolyte, Table S1: Results of the water and electrolyte uptake, in-plane conductivity and accelerated stress test of the NR212, FAP-450 and $m$-PBI membranes [36].

Author Contributions: Conceptualization, L.G.; methodology, L.G. and E.Z.; software, J.C.D.; validation, J.C.D. and E.Z.; formal analysis, J.C.D., E.Z., and K.A.; investigation, J.C.D.; data curation, J.C.D.; writing —original draft preparation, J.C.D., K.A., and E.Z.; writing—review and editing, E.Z., L.G., and T.J.S.; visualization, J.C.D. and E.Z.; supervision, E.Z., L.G., and T.J.S.; project administration, E.Z., S.P., and L.G.; funding acquisition, H.A.H. and L.G. All authors have read and agreed to the published version of the manuscript.

Funding: The research work at PSI reported here is supported by the Swiss National Science Foundation (grant number 188631) and jointly by the Swiss National Science Foundation and Innosuisse in the framework of the Bridge Discovery program (grant number 176653). Danish Power Systems, acquired by Blue World Technologies in Jan 2021, was supported by the Innovation fund of Denmark (DanFlow project, grant number: 9090-00059A) for this research.

Institutional Review Board Statement: Not applicable.

Informed Consent Statement: Not applicable.

Data Availability Statement: Data available on request. The data will be made available on a publicly accessible repository after the project completion.

Acknowledgments: The authors acknowledge A. Schneider (PSI) for his contribution to the conceptual idea behind the fabrication method of the composite membrane.

Conflicts of Interest: The authors declare no conflict of interest.

Sample Availability: Samples of the compounds are not available from the authors.

\section{References}

1. Gubler, L. Membranes and separators for redox flow batteries. Curr. Opin. Electrochem. 2019, 18, 31-36. [CrossRef]

2. Li, X.; Zhang, H.; Mai, Z.; Zhang, H.; Vankelecom, I. Ion exchange membranes for vanadium redox flow battery (VRB) applications. Energy Environ. Sci. 2011, 4, 1147-1160. [CrossRef]

3. Zeng, L.; Zhao, T.S.; Wei, L.; Jiang, H.R.; Wu, M.C. Anion exchange membranes for aqueous acid-based redox flow batteries: Current status and challenges. Appl. Energy 2019, 233-234, 622-643. [CrossRef]

4. Ye, R.; Henkensmeier, D.; Yoon, S.J.; Huang, Z.; Kim, D.K.; Chang, Z.; Kim, S.; Chen, R. Redox Flow Batteries for Energy Storage: A Technology Review. J. Electrochem. Energy Convers. Storage 2017, 15, 010801. [CrossRef] 
5. Gubler, L.; Vonlanthen, D.; Schneider, A.; Oldenburg, F.J. Composite Membranes Containing a Porous Separator and a Polybenzimidazole Thin Film for Vanadium Redox Flow Batteries. J. Electrochem. Soc. 2020, 167, 100502. [CrossRef]

6. Yuan, Z.; Duan, Y.; Zhang, H.; Li, X.; Zhang, H.; Vankelecom, I. Advanced porous membranes with ultra-high selectivity and stability for vanadium flow batteries. Energy Environ. Sci. 2016, 9, 441-447. [CrossRef]

7. Peng, S.; Yan, X.; Wu, X.; Zhang, D.; Luo, Y.; Su, L.; He, G. Thin skinned asymmetric polybenzimidazole membranes with readily tunable morphologies for high-performance vanadium flow batteries. RSC Adv. 2017, 7, 1852-1862. [CrossRef]

8. Chae, I.S.; Luo, T.; Moon, G.H.; Ogieglo, W.; Kang, Y.S.; Wessling, M. Ultra-High Proton/Vanadium Selectivity for Hydrophobic Polymer Membranes with Intrinsic Nanopores for Redox Flow Battery. Adv. Energy Mater. 2016, 6, 1600517. [CrossRef]

9. Tan, R.; Wang, A.; Malpass-Evans, R.; Williams, R.; Zhao, E.W.; Liu, T.; Ye, C.; Zhou, X.; Darwich, B.P.; Fan, Z.; et al. Hydrophilic microporous membranes for selective ion separation and flow-battery energy storage. Nat. Mater. 2020, 19, 195-202. [CrossRef]

10. Lee, W.; Jung, M.; Serhiichuk, D.; Noh, C.; Gupta, G.; Harms, C.; Kwon, Y.; Henkensmeier, D. Layered composite membranes based on porous PVDF coated with a thin, dense PBI layer for vanadium redox flow batteries. J. Membr. Sci. 2019, $591,117333$. [CrossRef]

11. Geng, K.; Li, Y.; Xing, Y.; Wang, L.; Li, N. A novel polybenzimidazole membrane containing bulky naphthalene group for vanadium flow battery. J. Membr. Sci. 2019, 586, 231-239. [CrossRef]

12. Noh, C.; Jung, M.; Henkensmeier, D.; Nam, S.W.; Kwon, Y. Vanadium Redox Flow Batteries Using meta-Polybenzimidazole-Based Membranes of Different Thicknesses. ACS Appl. Mater. Interfaces 2017, 9, 36799-36809. [CrossRef] [PubMed]

13. Krishnan, N.N.; Duong, N.M.H.; Konovalova, A.; Jang, J.H.; Park, H.S.; Kim, H.J.; Roznowska, A.; Michalak, A.; Henkensmeier, D. Polybenzimidazole/tetrazole-modified poly(arylene ether) blend membranes for high temperature proton exchange membrane fuel cells. J. Membr. Sci. 2020, 614, 118494. [CrossRef]

14. Aili, D.; Henkensmeier, D.; Martin, S.; Singh, B.; Hu, Y.; Jensen, J.O.; Cleemann, L.N.; Li, Q. Polybenzimidazole-Based HighTemperature Polymer Electrolyte Membrane Fuel Cells: New Insights and Recent Progress. Electrochem. Energy Rev. 2020, 3 , 793-845. [CrossRef]

15. Zhou, Z.; Zholobko, O.; Wu, X.-F.; Aulich, T.; Thakare, J.; Hurley, J. Polybenzimidazole-Based Polymer Electrolyte Membranes for High-Temperature Fuel Cells: Current Status and Prospects. Energies 2021, 14, 135. [CrossRef]

16. Cseri, L.; Baugh, J.; Alabi, A.; AlHajaj, A.; Zou, L.; Dryfe, R.A.W.; Budd, P.M.; Szekely, G. Graphene oxide-polybenzimidazolium nanocomposite anion exchange membranes for electrodialysis. J. Mater. Chem. A 2018, 6, 24728-24739. [CrossRef]

17. Ignacz, G.; Fei, F.; Szekely, G. Ion-Stabilized Membranes for Demanding Environments Fabricated from Polybenzimidazole and Its Blends with Polymers of Intrinsic Microporosity. ACS Appl. Nano Mater. 2018, 1, 6349-6356. [CrossRef]

18. Ding, L.; Song, X.; Wang, L.; Zhao, Z. Enhancing proton conductivity of polybenzimidazole membranes by introducing sulfonate for vanadium redox flow batteries applications. J. Membr. Sci. 2019, 578, 126-135. [CrossRef]

19. Maurya, S.; Shin, S.-H.; Lee, J.-Y.; Kim, Y.; Moon, S.-H. Amphoteric nanoporous polybenzimidazole membrane with extremely low crossover for a vanadium redox flow battery. RSC Adv. 2016, 6, 5198-5204. [CrossRef]

20. Yan, X.; Dong, Z.; Di, M.; Hu, L.; Zhang, C.; Pan, Y.; Zhang, N.; Jiang, X.; Wu, X.; Wang, J.; et al. A highly proton-conductive and vanadium-rejected long-side-chain sulfonated polybenzimidazole membrane for redox flow battery. J. Membr. Sci. 2020, 596, 117616. [CrossRef]

21. Wan, Y.H.; Sun, J.; Jiang, H.R.; Fan, X.Z.; Zhao, T.S. A highly-efficient composite polybenzimidazole membrane for vanadium redox flow battery. J. Power Sources 2021, 489, 229502. [CrossRef]

22. Oldenburg, F.J.; Nilsson, E.; Schmidt, T.J.; Gubler, L. Tackling Capacity Fading in Vanadium Redox Flow Batteries with Amphoteric Polybenzimidazole/Nafion Bilayer Membranes. ChemSusChem 2019, 12, 2620-2627. [CrossRef]

23. Zhou, X.L.; Zhao, T.S.; An, L.; Wei, L.; Zhang, C. The use of polybenzimidazole membranes in vanadium redox flow batteries leading to increased coulombic efficiency and cycling performance. Electrochim. Acta 2015, 153, 492-498. [CrossRef]

24. Wang, K.Y.; Chung, T.-S. Fabrication of polybenzimidazole (PBI) nanofiltration hollow fiber membranes for removal of chromate. J. Membr. Sci. 2006, 281, 307-315. [CrossRef]

25. Wang, K.Y.; Xiao, Y.; Chung, T.-S. Chemically modified polybenzimidazole nanofiltration membrane for the separation of electrolytes and cephalexin. Chem. Eng. Sci. 2006, 61, 5807-5817. [CrossRef]

26. Aili, D.; Jankova, K.; Han, J.; Bjerrum, N.J.; Jensen, J.O.; Li, Q. Understanding ternary poly(potassium benzimidazolide)-based polymer electrolytes. Polymer 2016, 84, 304-310. [CrossRef]

27. Mark, H.F.; Bikales, N.M.; Kroschwitz, J.I.; Overberger, C.G.; Menges, G. Encyclopedia of Polymer Science and Engineering, A to Amorphous Polymers; Wiley: Hoboken, NJ, USA, 1985.

28. Mai, Z.; Zhang, H.; Li, X.; Bi, C.; Dai, H. Sulfonated poly(tetramethydiphenyl ether ether ketone) membranes for vanadium redox flow battery application. J. Power Sources 2011, 196, 482-487. [CrossRef]

29. Hsu, W.Y.; Gierke, T.D. Ion transport and clustering in nafion perfluorinated membranes. J. Membr. Sci. 1983, 13, 307-326. [CrossRef]

30. Oldenburg, F.J.; Schmidt, T.J.; Gubler, L. Tackling capacity fading in vanadium flow batteries with amphoteric membranes. J. Power Sources 2017, 368, 68-72. [CrossRef]

31. Che, X.; Zhao, H.; Ren, X.; Zhang, D.; Wei, H.; Liu, J.; Zhang, X.; Yang, J. Porous polybenzimidazole membranes with high ion selectivity for the vanadium redox flow battery. J. Membr. Sci. 2020, 611, 118359. [CrossRef] 
32. Li, Q.; Aili, D.; Hjuler, H.A.; Jensen, J.O. High Temperature Polymer Electrolyte Membrane Fuel Cells: Approaches, Status, and Perspectives; Springer: Berlin/Heidelberg, Germany, 2016.

33. Seel, D.C.; Benicewicz, B.C.; Xiao, L.; Schmidt, T.J. High-temperature polybenzimidazol-based membranes. In Handbook of Fuel Cells; Wiley: Hoboken, NJ, USA, 2010.

34. Mader, J.; Xiao, L.; Schmidt, T.J.; Benicewicz, B.C. Polybenzimidazole/Acid Complexes as High-Temperature Membranes. In Fuel Cells II; Scherer, G.G., Ed.; Springer: Berlin/Heidelberg, Germany, 2008; pp. 63-124.

35. Xie, W.; Darling, R.M.; Perry, M.L. Processing and Pretreatment Effects on Vanadium Transport in Nafion Membranes. J. Electrochem. Soc. 2015, 163, A5084-A5089. [CrossRef]

36. Oldenburg, F.J.; Ouarga, A.; Schmidt, T.J.; Gubler, L. Accelerated Stress Test Method for the Assessment of Membrane Lifetime in Vanadium Redox Flow Batteries. ACS Appl. Mater. Interfaces 2019, 11, 47917-47928. [CrossRef]

37. Bouchet, R.; Siebert, E. Proton conduction in acid doped polybenzimidazole. Solid State Ion. 1999, 118, 287-299. [CrossRef]

38. Giffin, G.A.; Conti, F.; Lavina, S.; Majerus, A.; Pace, G.; Korte, C.; Lehnert, W.; Di Noto, V. A vibrational spectroscopic and modeling study of poly(2,5-benzimidazole) (ABPBI) - Phosphoric acid interactions in high temperature PEFC membranes. Int. J. Hydrog. Energy 2014, 39, 2776-2784. [CrossRef]

39. Aldrich, S. IR Spectrum Table \& Chart. Available online: https://www.sigmaaldrich.com/technical-documents/articles/biology/ ir-spectrum-table.html (accessed on 27 January 2020). 